\title{
Orexins/Hypocretins: Key Regulators of Energy Homeostasis
}

\author{
Edward Milbank ${ }^{1,2 *}$ and Miguel López ${ }^{1,2 *}$ \\ ${ }^{1}$ Department of Physiology, CIMUS, Instituto de Investigación Sanitaria, Santiago de Compostela, Spain, ${ }^{2}$ CIBER \\ Fisiopatología de la Obesidad y Nutrición (CIBERobn), Santiago de Compostela, Spain
}

OPEN ACCESS

Edited by:

Denis Richard

Laval University, Canada

Reviewed by:

Thomas Alexander Lutz,

University of Zurich, Switzerland Luigia Cristino,

Institute of Biomolecular Chemistry of

Italian Research Council, Italy

*Correspondence:

Edward Milbank

ed.milbank@usc.es

Miguel López

m.lopez@usc.es

Specialty section:

This article was submitted to Neuroendocrine Science,

a section of the journal

Frontiers in Endocrinology

Received: 16 November 2018

Accepted: 13 November 2019

Published: 10 December 2019

Citation:

Milbank E and López M (2019)

Orexins/Hypocretins: Key Regulators

of Energy Homeostasis.

Front. Endocrinol. 10:830.

doi: 10.3389/fendo.2019.00830
Originally described to be involved in feeding regulation, orexins/hypocretins are now also considered as major regulatory actors of numerous biological processes, such as pain, sleep, cardiovascular function, neuroendocrine regulation, and energy expenditure. Therefore, they constitute one of the most pleiotropic families of hypothalamic neuropeptides. Although their orexigenic effect is well documented, orexins/hypocretins also exert central effects on energy expenditure, notably on the brown adipose tissue (BAT) thermogenesis. A better comprehension of the underlying mechanisms and potential interactions with other hypothalamic molecular pathways involved in the modulation of food intake and thermogenesis, such as AMP-activated protein kinase (AMPK) and endoplasmic reticulum (ER) stress, is essential to determine the exact implication and pathophysiological relevance of orexins/hypocretins on the control of energy balance. Here, we will review the actions of orexins on energy balance, with special focus on feeding and brown fat function.

Keywords: orexins/hypocretins, hypothalamus, food intake, thermogenesis, brown adipose tissue

\section{INTRODUCTION}

Localized below the thalamus on the ventral face of the diencephalon, the hypothalamus is a master center for the integration of multiple signals and participates in the regulation of numerous homeostatic functions; the regulation of energy balance and endocrine axes being the most important ones (1-5). The hypothalamus is composed of anatomically distinct nuclei emitting numerous axonal projections interconnecting one region to another developing a complex neuronal circuit. One of the most important hypothalamic nuclei involved in the feeding regulation is the arcuate nucleus (ARC), which is composed by two main neuronal populations: (i) orexigenic (feeding-promoting) neurons co-expressing neuropeptide Y (NPY) and agouti-related protein (AgRP) and (ii) anorexigenic (feeding-inhibiting) ones co-expressing cocaine- and amphetamine- related transcript (CART) and pro-opiomelanocortin (POMC; the precursor of the alpha-melanocyte stimulating hormone, $\alpha-\mathrm{MSH}$ ). Following their integration by the ARC, the peripheral signals are transmitted by neuronal projections to other hypothalamic areas such as the dorsomedial nucleus (DMH), the paraventricular nucleus (PVH) and the lateral hypothalamic area (LHA). The ventromedial nucleus of the hypothalamus (VMH; localized above and laterally from the ARC on both sides of the third ventricle) is also receiving secondary neuronal information originating from the ARC. VMH neurons subsequently communicate, through neuronal projections, with other hypothalamic areas, such as DMH, LHA and ARC, as well as other cerebral regions, such as the dorsal motor nucleus of the vagus (DMV), the nucleus tractus solitarius (NTS), the raphe pallidus (RPa) and the inferior olive (IO) (1-5). 
The importance of the hypothalamus in the modulation of autonomic and endocrine functions was described for the first time more than 70 years ago $(1,5-11)$. A precise fine tuning of these functions is crucial for numerous physiological processes, such as drinking and feeding, thermoregulation, neuroendocrine control, reproduction/lactation, sleep-wake cycle, and cardiovascular function. Even if the role of LHA in the above described functions has been fully identified $(1,5-11)$, the underlying molecular mechanisms remained poorly studied until the latter part of the twentieth century, when the physiological role of some LHA-expressed neuropeptides was discovered, among then orexins/hypocretins.

\section{THE DISCOVERY OF OREXINS/HYPOCRETINS}

Melanin-concentrating hormone $(\mathrm{MCH})$ was the first discovered orexigenic peptide located specifically in the LHA (12-14). Other feeding related neuropeptides, such as galanin (GAL) (15), dynorphin (DYN) (16), and cocaine- and amphetamineregulated transcript peptides (CARTps) (17) have later also been described to be expressed in the LHA. Nevertheless, the most relevant finding has been the discovery in 1998 of a new family of neuropeptides: the orexins/hypocretins. Sutcliffe and colleagues, using the directional tag polymerase chain reaction subtraction, were able to identify a novel mRNA, which expression was limited to the LHA. This mRNA was described to encode a 130 -amino acid secretory protein composed of a proteolytic site engendering two C-terminally amidated peptides. Interestingly, significant homologies were observed between one of these generated peptides and the gut secretin peptide family. Therefore, due to their hypothalamic origins, they were named hypocretins (Hcrt1 and Hcrt2) (18). In parallel, Yanagisawa and colleagues identified two peptides using intracellular calcium influx in high orphan G-protein-coupled receptor expressing cells. They were able to determine that the two neuropeptides were originating from a common proteolytic processed LHA precursor, and, considering its hypothalamic location, they have suggested its potential role in feeding behavior. In line with this assessment, intracerebroventricular (ICV) administrations of these peptides in non-fasted rats stimulated food intake in a dose- and time-dependent fashion. Therefore, considering their orexigenic activities, these neuropeptides were named orexins (OX-A and OX-B) (19). Nowadays, orexins are known to participate widely in the regulation of numerous biological processes, such as sleep, energy expenditure, pain, cardiovascular function, and neuroendocrine regulation, making them one of the most pleiotropic families of hypothalamic neuropeptides $(9,20-26)$. In this regard, it is important to take into account that although most of the first studies on orexins were based on their administration through different routes and doses that were likely outside of a physiological range (see below), further studies using genetic modified animals (see below) have strengthen the pleiotropic role of this neuropeptide system.

Two orexin/hypocretin receptors were identified: the orexin/hypocretin 1 receptor (OX1R/Hcrtr1), having a highest affinity for OX-A, and the orexin/hypocretin 2 receptor (OX2R/Hcrtr2), having similar elevated affinity for both OX-A and OX-B (19). High levels of OXRs mRNA and proteins are encountered in the central nervous system. Molecular and immunohistochemistry studies have shown that OX1R neurons were highly expressed in rat hypothalamus, with a main distribution in the periventricular (PeN), PVH (magno- and parvocellular divisions), supraoptic (SON), ARC, VMH, DMH, and tuberomammillary (TMN) nuclei, as well as in the LHA (2730). Interestingly, OX1R and neuropeptides participating in the endocrine regulation are sharing the same central distribution. As an example, in the SON and in magnocellular neurons of the $\mathrm{PVH}, \mathrm{OX1 \textrm {R }}$ is expressed in arginine vasopressin $(\mathrm{ADH})$ and oxytocin (OT) neurons. Similar observations were performed in the suprachiasmatic nucleus (SCN) with an expression of OX1R (i) in $\mathrm{ADH}$ and vasoactive intestinal polypeptide (VIP) neurons, (ii) in the PeN with OX1R-somatostatin (SST) co-expressing neurons, and (iii) and in the parvocellular part of $\mathrm{PVH}$ with OX1R colocalized in corticotropin-releasing hormone (CRH) neurons (30). Moreover, OX1R is also expressed in the main neuronal populations constituting the ARC: POMC neurons of the ventrolateral part and NPY neurons of the ventromedial part (30). Moreover, OX1R expression was also detected in other brain regions of the rat such as in the septal preoptic area (SPOA), in the medial preoptic area MPOA $(27,29,31)$ and in gonadotropin-releasing hormone (GnRH) neurons (32). As OX1R, OX2R mRNAs is widely encountered within the brain with high levels in the ARC and LHA, in the medial parvocellular part of the $\mathrm{PVH}$, in the premammillary nucleus (PMN) and TMN. Within the VMH, DMH, PeN, in the posterior hypothalamus and the preoptic area (POA), the detected levels of OX2R mRNAs were lower, reaching really weak levels in the SPOA and in the dorsal and lateral parts of the PVH. Notably, OX2R mRNAs were not detected in the magnocellular neurons of the PVH $(27-29,33)$. OXRs wide distribution all around the central nervous system confirm their pleiotropic role. In terms of signal transduction, the binding of orexins to OX1R or OX2R stimulates Gq or Gi subtypes, which subsequently induce the activation of phospholipase C (PLC), phospholipase A (PLA), phospholipase D (PLD) or adenylyl cyclase (AC), ultimately resulting in an increase in cytosolic $\mathrm{Ca}^{2+}$ and a downstream cascade response. In addition, OX-A binds OX1R and stimulates $\mathrm{Ca}^{2+}$ release by activating non-selective cation channels (NSCCs) (34). Finally, OX1R receptor activation also promotes the enhancement of the synthesis of the endocannabinoid 2 -arachidonoylglycerol (2-AG) which is a master interplayer with OX-A in the regulation of energy homeostasis both at central and peripheral level $(35,36)$.

\section{OREXIN/HYPOCRETINS AND FOOD INTAKE}

The first physiological function attributed to the orexin system was the modulation of the feeding behavior. This was suggested following two major studies: (i) the hypothalamic expression of orexin precursor was increased during fasting $(19,37)$ and (ii) the 
pharmacological central administration of orexin in rats induced food intake (food consumption being dependent of the orexin injected dose) $(19,38-40)$. This feeding-promoting effect is not as robust as the one induced by NPY and AgRP, but it is considered as similar as the one initiated by $\mathrm{MCH}$ and GAL (38, 40-45). Although the precise effect of OX-B on feeding remains unclear, its orexigenic potential was described to be less potent than OXA $(38,41-46)$, which could be explained by differences in their secondary structures: OX-A being maintained by two disulphide bonds conferring resistance to peptidase actions (20).

Interestingly, in rat models, both central OX-A and OX$B$ administrations induced orexigenic effects. Conversely, when injected peripherally (acute or chronic), none of the orexins induced feeding variations (41), except one study in pigs showing that the subcutaneous injection of OX-B stimulated food intake (47). Moreover, orexin actions have been described to follow circadian patterns, with a maximal effect at the beginning of the light phase and at the middle of the dark one (observed when animals are satiated) $(40,41)$. These differences could be explained by the circadian variations of the endogenous levels of OX-A, described to be maximal at the beginning of the dark phase and minimal at the beginning of the light one $(48,49)$. Interestingly, orexigenic effects of orexins were also observed in non-mammalian species, such as in the goldfish (Carassius auratus) (administrated centrally with human OX-A) (50), suggesting a possible evolutionary conservation. However, another study led on neonatal chicks did not reveal any feeding variations following a central administration of orexins (51).

Although most of these evidences have been obtained following administrations of orexins at doses that are likely higher than the physiological range, some studies have also revealed an implication of the orexin system in the physiological control of feeding. As an example, the central administration of anti-OX-A antibodies in rats under fasting conditions inhibited feeding in a dose-dependent manner (52). In the same line of findings, OX1R antagonist (SB-334867-A) administrated intraperitoneally decreased food intake in both fed and fasting conditions (39). Interestingly, the administration of OX-A at small doses in hypothalamic nuclei such as PVH and LHA of rodent models stimulates food intake $(43,53)$, while the selective OX antagonist SB-334867 suppresses it $(39,54)$. Due to the OXA higher orexigenic potential compared to OX-B, these data implicate OX1R rather than OX2R in the modulation of feeding behavior $(39,55)$. These findings were confirmed using genetic modified mouse models, such as orexin knockout mice $\left(o x^{-/-}\right)$ (20) and orexin/ataxin-3 transgenic mice (in which orexincontaining neurons were abalated) (56), models that displayed hypophagic behaviors. Therefore, despite the unequivocal role of orexins in the modulation of other phycological processes, such as sleep (57-59), their physiological role in food intake control seems also clear.

In agreement with a physiological role of orexin system in feeding control, the orexigenic effects of orexins are mainly mediated by the NPY system located in the ARC (Figure 1). Interestingly, immunohistochemical studies have demonstrated that orexin axons possessed synaptic interactions with NPY/AgRP neurons in the ARC and with NPY axons in the PVH (60). In harmony with this, OX-A within the PVH modulates spontaneous firing of glucose-sensitive neurons and promotes food intake via the NPY pathway (61). Furthermore, selective antagonists of NPY Y1 and NPY Y5 receptors centrally administrated partially reverse orexin-induced feeding stimulation (45, 62-64). Lastly, the central administration of OXA stimulates NPY expression in the ARC, without affecting it in the DMH (40). Interestingly, AgRP, which is co-expressed with NPY in the ARC, was not modified upon OX-A treatment (40). Even if it may be argued that those central injections are given in a supra-physiological range, the involvement of alternative central mechanisms (i.e., NPY neurons) and the results obtained from ox null mice studies rule out the possibility of unspecific actions in terms of feeding control. In this sense, comparable results regarding feeding and alterations of NPY mRNA expression were observed in goldfish (65), suggesting a possible interaction between orexin and NPY systems to stimulate food intake (40, 65), which notably is evolutionary preserved, at least until the fish lineage. OX-A feeding effects have also been associated to other central mechanisms modulating food intake, such as endocannabinoids (66) CRH (45), urocortin, and melanocortins (67). In this regard, LHA orexin expression has been described to be higher in Pomc null mice, with a reversion following a central administration of $\alpha-\mathrm{MSH}$ (68). As the orexin expression remained elevated in pomc null mice pair-fed (taking $\alpha$-MSHtreated animals as a reference), this effect was independent of the primary actions of $\alpha-\mathrm{MSH}$ on food intake. These data indicate that the elevation in orexin levels may be related to the hyperphagia observed in melanocortin deficient mice. To further support this evidence, that $o b / o b$ mice show higher levels of OX-A in the ARC in concomitance with a reduction on pomc expression (35). Moreover, the OX-A-induced reduction of pomc mRNA expression and $\alpha$-MSH production is reversed by administration of SB-334867 in obese mice (35).

Aside from their major role in the stimulation of food intake, orexins were also described to be involved in the sleep/wake cycling and pathology of narcolepsy (57-59). Numerous evidences-such as the loss of orexin containing neurons, mutations occurring in prepro-OX and OXRs, or reductions in cerebrospinal fluid (CSF) OX-A levels -, have linked orexins and narcolepsy in different species such as dogs, mice, rats or humans $(20,56-59,69,70)$. Apart from their implication in sleep/wake modulation, orexins are also involved in arousal regulation. Numerous anatomical evidences-orexin neuronal projections into PVH, locus coeruleus (LC) and dorsal raphe $(71,72)$ (main sites of productions of $\mathrm{CRH}$, norepinephrine and serotonin) -, have confirmed this orexin/arousal regulation connection. Indeed, the central injections of orexins in rats induced different physiological behaviors, such as grooming [indicating a circadian dependence (73)], face washing, burrowing and searching (74-77). Altogether, these evidences have suggested that orexin feeding stimulation could rather be due to an increase of activity during the awake state (73) and to their stimulatory effect on arousal and vigilance, two features essential for normal feeding (74). Nevertheless, OX-A actions on feeding were described to be independent of arousal stimulation $(20,78)$. 


\section{NUTRIENT SENSING BY OREXINS/HYPOCRETINS}

The orexin system is able to detect any changes in energy balance, such as fasting that leads to an increase of orexin mRNA and protein levels in rat hypothalamus $(19,37,79,80)$. In line with these findings, orexin neurons localized in the LHA can sense leptin and glucose levels. Actually, in orexin neurons, in an insulin-induced hypoglycaemia state, c-FOS (81) and hypothalamic prepro-OX mRNA $(82,83)$ expression are increased. Thus, a drastic decrease of glycaemia, detected by glucose-sensitive neurons (GSNs), could promote food intake. Interestingly, orexin axons have synaptic contacts with GSNs, and spontaneous GSNs firing rate is increased following OX-A release $(61,84-86)$. Accordingly, elevated blood glucose levels decrease orexin neurons firing rates, implying that orexins could be implicated in a negative feedback loop in order to counter any energetic variations (87). Moreover, it has also been described that orexin at a central level could bidirectionally modulate hepatic gluconeogenesis, engendering daily blood glucose oscillation (88-90). It was also described that aging could alter this regulation, being implicated in the circadian modulation of hepatic insulin. Indeed, the absence of orexin increases hepatic endoplasmic reticulum (ER) stress leading to decreased hepatic insulin sensitivity and altered gluconeogenic activity (90).

It was also proposed that leptin, a hormone released by the adipose tissue, could exert its appetite suppressant effect through the inhibition of orexin neurons activity (91). In this sense, it has been recently reported that OX neurons of $o b / o b$ mice are innervated by less efficient and fewer excitatory synapses than wildtype mice. Moreover, in $o b / o b$ mice, chronic absence of leptin induces a 2-AG mediated functional disinhibition of OX neurons, which would lead to increased OX production and therefore hyperphagia (92). Those things said, the interaction between leptin and orexins is complex. Indeed, controversial results are presented in the literature concerning the presence of leptin receptors on orexin neurons: while some are describing a colocalization $(60,93,94)$, others were unable to do so $(95,96)$. Interestingly, the high levels of prepro-OX and OX1R mRNA encountered in rat hypothalamus under fasting conditions were decreased following an administration of leptin $(19,37)$. Furthermore, LHA orexin-A expression is reduced following leptin administration (97). In the same line of findings, it was demonstrated that in human plasma, the levels of OX-A were negatively correlated with the ones of leptin $(35,98)$. Despite these observations, low prepro-OX mRNA and high OXRs mRNA levels have been observed in the brains of obese Zucker rats $(99,100)$. Similar unexpected results were observed in $o b / o b$ and $d b / d b$ mice, in which low levels of prepro-OX mRNA in the LHA were detected, likely due to hyperglycemia (101). Recently, it has been proposed that leptin and orexin could act in a synergic manner in order to regulate energy sensing, particularly in the long term (102). In summary, regarding the close and complex interaction between orexin neurons and leptin signaling, further investigation would be needed to obtain an improved overview of all these mechanisms.
Ghrelin, an orexigenic hormone released by the gut, stimulates orexin neurons $(103,104)$. It was demonstrated that ghrelin could increase the rewarding value of palatable food through the stimulation of dopaminergic neurons located in the ventral tegmental area (VTA); this effect being inhibited using orexin antagonists $(96,105,106)$. Despite these findings, it was demonstrated that the levels of prepro-OX mRNA were not modified after a treatment with ghrelin (107). Eventually, it has been suggested that feeding-related signals originating from the gut could modulate orexin signaling, via the vagus nerve and the NTS. Consequently, different stimuli, such as gastric expansion or glucose variations could act as feeding suppressing signals, having an important role in the regulation of orexin signaling $(85,108)$.

Recently, our group has demonstrated an interaction between the hypothalamic-pituitary axes and the central orexigenic action of OX-A. Hypophysectomized (HPX), adrenalectomized (ADX), gonadectomized (GNX; females and males), hypothyroid and $\mathrm{GH}$-deficient dwarf rats were centrally injected with OX-A. Interestingly, we were able to show that the orexigenic effect of OX-A was completely maintained in ADX and GNX rats, slightly decreased in hypothyroid rats and entirely inhibited in hypophysectomized and dwarf rats (109). Remarkably, the loss of the OX-A effect on feeding was coupled with a blunted OX-A-induced increase of NPY or of its putative regulator, the transcription factor cAMP response-element binding protein (CREB), as well as its phosphorylated form pCREB, in the ARC of HPX and dwarf rats (109). All these results highlight the fact that the orexigenic effect induced by OX-A is dependent of the integrity of the GH axis (109). Moreover, our group has also demonstrated that OX-A inhibited GH secretion in vivo (110). Thus, this neuroendocrine feedback regulation could help to obtain a better understanding of orexin role in energy balance modulation and GH deficiency.

Recently, some growing evidences have linked orexin signaling to the amino acid (AA) sensing (111). Indeed, Karnani and colleagues have shown that nutritionally relevant mixtures of amino acids could stimulate orexin neurons both in vitro and in vivo (following peripheral and central administration). They have also proposed that this effect could be mediated by a dual mechanism involving the inhibition of $\mathrm{K}(\mathrm{ATP})$ channels and the activation of system-A amino acid transporters. Interestingly, they were also able to show that physiological concentrations of AAs inhibited the glucose responses of orexin neurons (111).

\section{OREXIN/HYPOCRETINS AND THERMOGENESIS}

The energetic metabolism relies on an accurate balance between energy intake and energy expenditure. Energy intake is mainly defined by the sum of caloric content of the ingested food and beverage. On the other side, energy expenditure is the sum of the thermic effect of food, locomotor activity and thermogenesis (112-114). Interestingly, the obligatory thermogenesis-defined as the heat produced by the metabolic rate-is enough to preserve the body temperature at adequate levels without involving 
any other thermoregulatory mechanisms. The temperature range in which the organism does not need to regulate its body temperature is called thermoneutrality (112-114). Temperatures below the thermoneutrality point lead to an immediate and quick response through the activation of heat saving mechanisms such as vasoconstriction or piloerection. However, this primary response only provides limited effects on maintaining body temperature. Thus, additional thermogenic mechanisms - referred to facultative or adaptive thermogenesisare quickly initiated (112-114). These mechanisms are separated between shivering and non-shivering facultative thermogenesis. Shivering is an elementary response producing small amount of heat in cold-exposed organism (112-114). The evolutionary process allowed homoeothermic species to improve those mechanisms using metabolic machinery to generate heat in a more efficient way, named as non-shivering facultative thermogenesis. In mammals, including humans, the majority of non-shivering facultative thermogenesis is occurring in the brown adipose tissue (BAT) (112-114). BAT thermogenic capacities are mainly mediated by uncoupling protein 1 (UCP1), localized in the inner mitochondrial membrane. UCP1 dissociates the electron transport chain from ATP production by allowing the free movement of protons back across the mitochondrial membrane, increasing the energy dissipation as heat (112-114).

Since a long time, it is well known that the stimulation of $\operatorname{LHA}$ activates $\operatorname{BAT}(1,6,7,26,115,116)$. In the same line of findings, numerous studies, including pharmacological experiments and genetic modified mouse models, highlighted the fact that orexins promoted energy expenditure. Indeed, OXA centrally administrated in mice under fasting increased the metabolic rate $(117,118)$ and induces a hyperthermic response (119). Ox null mice developed a hypometabolic phenotype (57) and more sensitivity to cold exposure (120). Conversely, OXA centrally administrated has also been described to induce hypothermic effects, through a NPY-dependent mechanism (121, 122). Intriguingly, another study has reported that OX-B could induce hyperthermic effects (122). Interestingly, these effects can be reproduced by an OX-B administration into the diagonal band of Broca (123). The exact significance of the orexin induced thermogenic effect is still questionable, but it has been proposed that it could be an adaptive response to stress (124) or to cold exposure (120).

Molecular studies have revealed that orexins could modulate both locomotor activity and BAT thermogenesis to induce their effects on energy expenditure (125-130). Recently, it has been reported that orexins were essential for BAT development, differentiation, and function (125). As observed in ox null mice, the lack of orexin deregulates energy balance (120, 125). This evidence is also supported by in vitro studies that have revealed a direct implication of orexin on new brown adipocytes differentiation $(125,129)$. Morphological analysis has also shown that orexin neurons were implicated in the modulation of BAT thermogenesis through the SNS (Figure 1). Accordingly, (i) the central administration of OX-A or OX-B, (ii) the stimulation of orexin neurons in the LHA or (iii) the injection of OX-A specifically into the $\mathrm{VMH}$ or in the $\mathrm{RPa}$ promoted BAT thermogenesis $(116,126,128,131-133)$ while (iv) rats with ataxin-3 mediated ablation of orexin neurons showed reduced BAT thermogenesis $(134,135)$. Even if the mechanisms underlying these effects remain unclear, it was recently reported that AMP-activated protein kinase (AMPK), a cellular energy sensor $(5,136,137)$, and endoplasmic reticulum stress (ER stress), a cellular process that is triggered by a variety of conditions that disturb folding of proteins in the ER (138140 ), were the main modulators of BAT thermogenesis in the VMH (Figure 1) (5, 120, 141-155). Thus, it seems essential to pursue the investigation to understand how orexins, AMPK and ER stress could interact to modulate BAT thermogenesis in the hypothalamus. In this sense, recent data from our group have demonstrated that the thermogenic effect of the bone morphogenetic protein $8 \mathrm{~B}$ (BMP8B, a thermogenic factor initially involved in bone morphogenesis) $(120,143)$ on BAT (as well as the browning of white fat) is mediated by the inhibition of AMPK in the VMH and by the subsequent increase in OX signaling via the OX1R. Accordingly, the thermogenic effect of BMP8B is totally absent in ox null mice implicating glutamatergic signaling, indicating a physiological role of orexins in this regard (120). To understand whether these effects could also involve hypothalamic ER stress would require further investigations, however considering that the link AMPK-ceramide-inducedER stress has already been demonstrated for thyroid hormones (153), it is tempting to speculate a possible role on orexin actions. Additional investigations would be needed to further understand the role of orexins on BAT function and whether this action could have evolutionary implications related to adaptations to environmental temperature. Therefore, it will be demanding to investigate the effect of orexins and its postulated downstream and upstream regulators (for example AMPK) at different temperatures, such as cold exposure and thermoneutral conditions.

Recently, it has also been reported that orexin could have a protective role in aging-associated impaired thermogenesis (130). It is well known that aging induces an increase in fat mass, however the underlying mechanisms are still unknown. Numerous evidences have shown that aging was associated with impaired differentiation of BAT, morphologic malformations and thermogenic dysfunctions in rodents (130). This loss of function can be explained by the fact that in aged mice, the interscapular brown fat region is invaded by white-like adipocytes (130). Additionally, old mice are unable to mobilize brown adipocyte intracellular energetic reserves leading to an impaired regulation of basal thermogenesis. Interestingly, OX-A administration reverses these effects; while they were described to be potentialized in mouse with ablated OX neurons (130). Further investigations are needed to evaluate whether the orexin system could be a potential target to reverse the fat mass increase associated with aging. In this regard, considering the involvement of orexin in pathophysiology in humans (i.e., narcolepsy), and the presence of brown/browned fat in humans $(149,156-159)$, another important question to answer is whether orexins may play a role in the modulation of BAT in humans. Current evidence has demonstrated that contrary to rodents, OX-A treatment alone or in combination with an adrenergic stimulus did neither enhance thermogenesis nor its related 


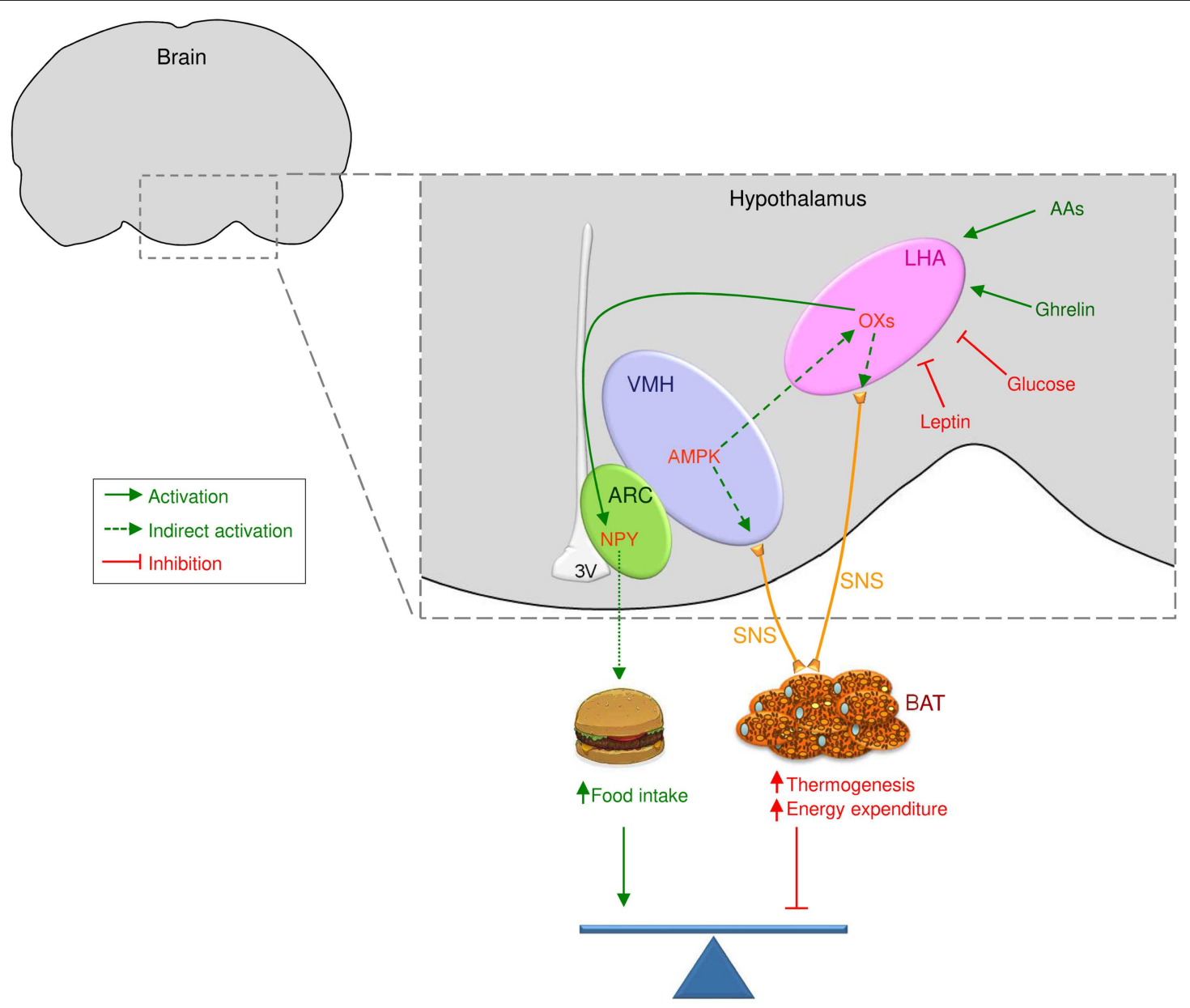

Body weight

FIGURE 1 | Central actions of orexins/hypocretins on food intake and BAT thermogenesis. Orexin/hypocretin neurons sense peripheral levels of metabolites, such as glucose and amino acids, and hormones, such as leptin and ghrelin, to control energy homeostasis. Therefore, orexin/hypocretin neurons in the lateral hypothalamic area (LHA) modulate food intake acting on neuropeptide Y (NPY) neurons in the arcuate nucleus of the hypothalamus (ARC). On the other hand, AMP-activated protein kinase (AMPK) in the ventromedial nucleus of the hypothalamus (VMH) impacts orexin neurons in the LHA to modulate brown adipose tissue (BAT) thermogenesis through the sympathetic nervous system (SNS, indicated by yellow lines). Whether OX may impact other central mechanism modulating thermogenesis, such as endoplasmic reticulum stress (ER stress) within the $\mathrm{VMH}$ will require further investigation.

transcriptional program in a human in vitro model of brown adipocytes or adipose tissue explants (160). These results are in keeping with data demonstrating that although narcolepsy patients show abnormal fat distribution (161), they do not display differences in the amount of supraclavicular BAT (161). Moreover, it has been shown that BAT is perfectly functional after cold exposure in patients with narcolepsy (162). Overall, this evidence indicates that the role of orexins on BAT activity in human is at least controversial. Further work will be required for a deeper investigation that will allow to address whether the effects of orexins on BAT are a specific phenomenon for rodents or, alternatively, a pathway that might be susceptible of therapeutic intervention in humans.

One interesting point is that orexins are primarily stimulated by fasting and starvation, a situation in which animals display hypothermia, reduced oxygen consumption and blunted thermogenic responses. Overall, these responses could seem contradictory with the physiological role of orexins as stimulators of BAT activity. However, the role of orexins in each scenario is totally dependent of other factors such as (i) the hormonal milieu (for example, ghrelin, leptin and thyroid hormone levels), (ii) the upstream and downstream hypothalamic molecular pathways and (iii) the hypothalamic nucleus specificity. In a fasting scenario, considering the role of orexin neurons as sensors of the outer and inner environment to reach a state of vigilance and wakefulness for seeking food, an increase of the orexigenic tone could be expected $(22,25)$. The mechanisms leading to this increase of orexin levels are numerous, including ghrelin and leptin which are essential as they play opposite role on orexin neurons (an increase in ghrelin levels and a decrease 
in leptin ones is observed during fasting) (37, 87). Ghrelin activates isolated orexin neurons inducing their depolarization and an increase in firing frequency (87). In contrast, leptin, a strong anorectic factor, robustly inhibits orexin neurons, causing hyperpolarization and decreasing the firing rate (87). This is the reason why in mice lacking orexin neurons, the fastinginduced arousal is impaired (87). On the other hand, conclusive evidence exists demonstrating that under normal feeding status, orexin neurons activate BAT through a mechanism involving elevated AMPK activity and expression in the VMH $(5,120)$. This blunted response in starvation is not so surprising as it reminds similar phenomena observed with thyroid hormones, in which, their effects on thermogenesis are also blunted. Under these circumstances, there is a change in the set point governing the entire hypothalamic-pituitary-thyroid axis to save as much energy as possible to ensure survival (114). In other words, under starvation conditions, the orexin system is activated allowing food-seeking, while the signaling mechanisms implicated in increasing thermogenesis are blunted to preserve energy. The exact mechanisms governing this later phenomenon remain unknown but it clearly merits to be pursued. However, some hypotheses can be speculated. During fasting, increased orexin levels were shown to induce feeding by stimulating NPY neurons in the ARC (40), which are also stimulated by the fasting-induced increase in ghrelin and the fasting-induced decrease in leptin (107). NPY neurons are known to inhibit thyrotropin-releasing hormone (TRH) neurons in the $\mathrm{PVH}$, leading to decreased thyroid-stimulating hormone (TSH) release from the pituitary and subsequently reduced circulating thyroid hormones and reduced thermogenesis $(114,141,153,163,164)$. Notably, as a result of the decreased thyroid hormone tone, most of that effect could be mediated by increased AMPK in the VMH (acting upstream of orexin) $(114,120,141,153,163,164)$. Therefore, the interplay between hormonal factors (ghrelin, leptin, thyroid hormones), neuropeptides (NPY and orexin) and energy sensors (AMPK) could be implicated into this complex regulation. Another possible scenario might be an adaptation to cold temperatures, a situation in which both thyroid hormones and orexins are known to be elevated $(114,134,135)$, which would lead to (i) increased BAT thermogenesis (induced by both thyroid hormones and orexins) and (ii) increased feeding (again,

\section{REFERENCES}

1. Saper CB, Lowell BB. The hypothalamus. Curr Biol. (2014) 24:R1111-6. doi: 10.1016/j.cub.2014.10.023

2. Richard D. Cognitive and autonomic determinants of energy homeostasis in obesity. Nat Rev Endocrinol. (2015) 11:489-501. doi: $10.1038 /$ nrendo. 2015.103

3. Gautron L, Elmquist JK, Williams KW. Neural control of energy balance: translating circuits to therapies. Cell. (2015) 161:133-45. doi: 10.1016/j.cell.2015.02.023

4. Waterson MJ, Horvath TL. Neuronal regulation of energy homeostasis: beyond the hypothalamus and feeding. Cell Metab. (2015) 22:962-970. doi: 10.1016/j.cmet.2015.09.026

5. López M, Nogueiras R, Tena-Sempere M, Dieguez C. Hypothalamic AMPK: a canonical regulator of whole-body energy balance. induced by both thyroid hormones and orexins) to cope the higher metabolic demands of thermogenesis. Similar thoughts are described for BMP8B, which induces thermogenesis, acting on orexin neurons in the LHA and AMPK in the VMH (120). Therefore, the pleiotropic role of orexins, as well as the redundancy of the hypothalamic networks modulating whole body energy homeostasis, are determining the response in each physiological condition.

\section{CONCLUDING REMARKS}

All throughout this review was described the implication of the orexin and hypocretin systems in the control of energy balance (Figure 1). Even if their roles in the regulation of the two components of the energy balance, namely feeding and energy expenditure, are well characterized, their involvement in the development in obese disorders remain unclear and debated. Indeed, orexin, centrally administrated, did not induced any body weight modifications (42) as well as prepro-OX mRNA levels remained unchanged in diet-induced and genetic models of obesity $(165,166)$. However, as mentioned above, the major role of orexins in the regulation of energy balance is undeniable. However, due to their pleiotropic characteristics, considering them as potential therapeutic targets in an obesity driven context appears as limited (167). To overcome these actual limits, a better understanding of orexin interaction with other known, or even unknown, systems involved in energy balance control would be necessary.

\section{AUTHOR CONTRIBUTIONS}

All authors listed have made a substantial, direct and intellectual contribution to the work, and approved it for publication.

\section{FUNDING}

This work has received funding from Xunta de Galicia (2015CP079), Ministry of Economy and Competitiveness (RTI2018101840-B-I00) and AtresMedia. CIBER de Fisiopatología de la Obesidad y Nutrición is an initiative of ISCIII. The funders had no role in decision to publish, or preparation of the manuscript. 
10. Schneeberger M, Gomis R, Claret M. Hypothalamic and brainstem neurocircuitries controlling homeostatic energy balance. J Endocrinol. (2014) 220:T25-46. doi: 10.1530/JOE-13-0398

11. Seoane-Collazo P, Ferno J, Gonzalez F, Dieguez C, Leis R, Nogueiras R, Lopez M. Hypothalamic-autonomic control of energy homeostasis. Endocrine. (2015) 50:276-91. doi: 10.1007/s12020-015-0658-y

12. Skofitsch G, Jacobowitz DM, Zamir N. Immunohistochemical localization of a melanin concentrating hormone- like peptide in the rat brain. Brain Res Bull. (1985) 15:635-49. doi: 10.1016/0361-9230(85)90213-8

13. Bittencourt JC, Presse F, Arias C, Peto C, Vaughan J, Nahon JL, Vale $\mathrm{W}$, Sawchenko PE. The melanin-concentrating hormone system of the rat brain: an immuno- and hybridization histochemical characterization. J Comp Neurol. (1992) 319:218-45. doi: 10.1002/cne.903190204

14. Qu D, Ludwig DS, Gammeltoft S, Piper M, Pelleymounter MA, Cullen MJ, et al. A role for melanin-concentrating hormone in the central regulation of feeding behaviour. Nature. (1996) 380:243-7. doi: 10.1038/380243a0

15. Hakansson ML, Brown H, Ghilardi N, Skoda RC, Meister B. Leptin receptor immunoreactivity in chemically defined target neurons of the hypothalamus. J Neurosci. (1998) 18:559-72. doi: 10.1523/JNEUROSCI.18-01-00559.1998

16. Chou TC, Lee CE, Lu J, Elmquist JK, Hara J, Willie JT, et al. Orexin (hypocretin) neurons contain dynorphin. J Neurosci. (2001) 21:RC168. doi: 10.1523/JNEUROSCI.21-19-j0003.2001

17. Koylu EO, Couceyro PR, Lambert PD, Kuhar MJ. Cocaine- and amphetamine-regulated transcript peptide immunohistochemical localization in the rat brain. J Comp Neurol. (1998) 391:115-32.

18. de Lecea L, Kilduff TS, Peyron C, Gao X, Foye PE, Danielson PE, et al. The hypocretins: hypothalamus-specific peptides with neuroexcitatory activity. Proc Natl Acad Sci USA. (1998) 95:322-7. doi: 10.1073/pnas.95.1.322

19. Sakurai T, Amemiya A, Ishii M, Matsuzaki I, Chemelli RM, Tanaka H, et al. Orexins and orexin receptors: a family of hypothalamic neuropeptides and $\mathrm{G}$ protein-coupled receptors that regulate feeding behavior. Cell. (1998) 92:573-85. doi: 10.1016/S0092-8674(00)80949-6

20. Willie JT, Chemelli RM, Sinton CM, Yanagisawa M. To eat or to sleep? Orexin in the regulation of feeding and wakefulness. Annu Rev Neurosci. (2001) 24:429-58. doi: 10.1146/annurev.neuro.24.1.429

21. Tsujino N, Sakurai T. Orexin/hypocretin: a neuropeptide at the interface of sleep, energy homeostasis, and reward system. Pharmacol Rev. (2009) 61:162-76. doi: 10.1124/pr.109.001321

22. López M, Tena-Sempere M, Diéguez C. Cross-talk between orexins (hypocretins) and the neuroendocrine axes (hypothalamic-pituitary axes). Front Neuroendocrinol. (2009) 31:113-27. doi: 10.1016/j.yfrne.2009.07.001

23. Herzig KH, Purhonen AK. Physiology and pathophysiology of hypocretins/orexins. Acta Physiol. (2010) 198:199-200. doi: $10.1111 /$ j.1748-1716.2010.02076.x

24. Sakurai T. The role of orexin in motivated behaviours. Nat Rev Neurosci. (2014) 15:719-31. doi: 10.1038/nrn3837

25. Gao XB, Horvath T. Function and dysfunction of hypocretin/orexin: an energetics point of view. Annu Rev Neurosci. (2014) 37:101-16. doi: 10.1146/annurev-neuro-071013-013855

26. Ferno J, Senaris R, Dieguez C, Tena-Sempere M, Lopez M. Orexins (hypocretins) and energy balance: more than feeding. Mol Cell Endocrinol. (2015) 418 (Pt 1):17-26. doi: 10.1016/j.mce.2015.07.022

27. Trivedi P, Yu H, MacNeil DJ, Van Der Ploeg LH, Guan XM. Distribution of orexin receptor mRNA in the rat brain. FEBS Lett. (1998) 438:71-5. doi: 10.1016/S0014-5793(98)01266-6

28. Lu XY, Bagnol D, Burke S, Akil H, Watson SJ. Differential distribution and regulation of $\mathrm{OX} 1$ and $\mathrm{OX} 2$ orexin/hypocretin receptor messenger RNA in the brain upon fasting. Horm Behav. (2000) 37:335-44. doi: 10.1006/hbeh.2000.1584

29. Marcus JN, Aschkenasi CJ, Lee CE, Chemelli RM, Saper CB, Yanagisawa M, et al. Differential expression of orexin receptors 1 and 2 in the rat brain. $J$ Comp Neurol. (2001) 435:6-25. doi: 10.1002/cne.1190

30. Backberg M, Hervieu G, Wilson S, Meister B. Orexin receptor-1 (OX-R1) immunoreactivity in chemically identified neurons of the hypothalamus: focus on orexin targets involved in control of food and water intake. Eur J Neurosci. (2002) 15:315-28. doi: 10.1046/j.0953-816x.2001.01859.x

31. Hervieu GJ, Cluderay JE, Harrison DC, Roberts JC, Leslie RA. Gene expression and protein distribution of the orexin-1 receptor in the rat brain and spinal cord. Neuroscience. (2001) 103:777-97. doi: 10.1016/S0306-4522(01)00033-1

32. Campbell RE, Grove KL, Smith MS. Gonadotropin-releasing hormone neurons coexpress orexin 1 receptor immunoreactivity and receive direct contacts by orexin fibers. Endocrinology. (2003) 144:1542-8. doi: 10.1210/en.2002-220958

33. Cluderay JE, Harrison DC, Hervieu GJ. Protein distribution of the orexin2 receptor in the rat central nervous system. Regul Pept. (2002) 104:131-44. doi: 10.1016/S0167-0115(01)00357-3

34. Wang C, Wang Q, Ji B, Pan Y, Xu C, Cheng B, et al. The orexin/receptor system: molecular mechanism and therapeutic potential for neurological diseases. Front Mol Neurosci. (2018) 11:220. doi: 10.3389/fnmol.2018.00220

35. Morello G, Imperatore R, Palomba L, Finelli C, Labruna G, Pasanisi F, et al. Orexin-A represses satiety-inducing POMC neurons and contributes to obesity via stimulation of endocannabinoid signaling. Proc Natl Acad Sci USA. (2016) 113:4759-64. doi: 10.1073/pnas.1521304113

36. Berrendero F, Flores A, Robledo P. When orexins meet cannabinoids: Bidirectional functional interactions. Biochem Pharmacol. (2018) 157:43-50. doi: 10.1016/j.bcp.2018.08.040

37. López M, Seoane L, García MC, Lago F, Casanueva FF, Senarís R, et al. Leptin regulation of prepro-orexin and orexin receptor mRNA levels in the hypothalamus. Biochem Biophys Res Commun. (2000) 269:41-5. doi: 10.1006/bbrc.2000.2245

38. Edwards CM, Abusnana S, Sunter D, Murphy KG, Ghatei MA, Bloom SR. The effect of the orexins on food intake: comparison with neuropeptide Y, melanin-concentrating hormone and galanin. J Endocrinol. (1999) 160:R712. doi: 10.1677/joe.0.160r007

39. Haynes AC, Jackson B, Chapman H, Tadayyon M, Johns A, Porter $\mathrm{RA}$, et al. A selective orexin-1 receptor antagonist reduces food consumption in male and female rats. Regul Pept. (2000) 96:45-51. doi: 10.1016/S0167-0115(00)00199-3

40. López M, Seoane LM, García MC, Diéguez C, Señarís R. Neuropeptide $\mathrm{Y}$, but not agouti-related peptide or melanin-concentrating hormone, is a target Peptide for orexin-a feeding actions in the rat hypothalamus. Neuroendocrinology. (2002) 75:34-44. doi: 10.1159/000048219

41. Haynes AC, Jackson B, Overend P, Buckingham RE, Wilson S, Tadayyon M, et al. Effects of single and chronic intracerebroventricular administration of the orexins on feeding in the rat. Peptides. (1999) 20:1099-105. doi: 10.1016/S0196-9781(99)00105-9

42. Yamanaka A, Sakurai T, Katsumoto T, Yanagisawa M, Goto K. Chronic intracerebroventricular administration of orexin-A to rats increases food intake in daytime, but has no effect on body weight. Brain Res. (1999) 849:248-52. doi: 10.1016/S0006-8993(99)01905-8

43. Dube MG, Kalra SP, Kalra PS. Food intake elicited by central administration of orexins/hypocretins: identification of hypothalamic sites of action. Brain Res. (1999) 842:473-7. doi: 10.1016/S0006-8993(99)01824-7

44. Sweet DC, Levine AS, Billington CJ, Kotz CM. Feeding response to central orexins. Brain Res. (1999) 821:535-8. doi: 10.1016/S0006-8993(99)01136-1

45. Ida T, Nakahara K, Kuroiwa T, Fukui K, Nakazato M, Murakami T, et al. Both corticotropin releasing factor and neuropeptide $\mathrm{Y}$ are involved in the effect of orexin (hypocretin) on the food intake in rats. Neurosci Lett. (2000) 293:119-22. doi: 10.1016/S0304-3940(00)01498-1

46. Sartin JL, Dyer C, Matteri R, Buxton D, Buonomo F, Shores M, et al. Effect of intracerebroventricular orexin-B on food intake in sheep. J Anim Sci. (2001) 79:1573-7. doi: 10.2527/2001.7961573x

47. Dyer CJ, Touchette KJ, Carroll JA, Allee GL, Matteri RL. Cloning of porcine prepro-orexin cDNA and effects of an intramuscular injection of synthetic porcine orexin-B on feed intake in young pigs. Domest Anim Endocrinol. (1999) 16:145-8. doi: 10.1016/S0739-7240(99)00011-9

48. Taheri S, Ward H, Ghatei M, Bloom S. Role of orexins in sleep and arousal mechanisms. Lancet. (2000) 355:847. doi: 10.1016/S0140-6736(05)72463-6

49. Fujiki N, Yoshida Y, Ripley B, Honda K, Mignot E, Nishino S. Changes in CSF hypocretin-1 (orexin A) levels in rats across 24 hours and in response to food deprivation. Neuroreport. (2001) 12:993-7. doi: 10.1097/00001756-200104170-00026

50. Volkoff H, Bjorklund JM, Peter RE. Stimulation of feeding behavior and food consumption in the goldfish, Carassius auratus, by orexin-A and orexin-B. Brain Res. (1999) 846:204-9. doi: 10.1016/S0006-8993(99)02052-1 
51. Furuse $M$, Ando R, Bungo $T$, Ao R, Shimojo $M$, Masuda $Y$. Intracerebroventricular injection of orexins does not stimulate food intake in neonatal chicks. Br Poult Sci. (1999) 40:698-700. doi: 10.1080/00071669987115

52. Yamada H, Okumura T, Motomura W, Kobayashi Y, Kohgo Y. Inhibition of food intake by central injection of anti-orexin antibody in fasted rats. Biochem Biophys Res Commun. (2000) 267:527-31. doi: 10.1006/bbrc.1999.1998

53. Thorpe AJ, Mullett MA, Wang C, Kotz CM. Peptides that regulate food intake: regional, metabolic, and circadian specificity of lateral hypothalamic orexin A feeding stimulation. Am J Physiol Regul Integr Comp Physiol. (2003) 284:R1409-17. doi: 10.1152/ajpregu.00344.2002

54. Rodgers RJ, Halford JC, Nunes de Souza RL, Canto de Souza AL, Piper DC, Arch JR, et al. SB-334867, a selective orexin-1 receptor antagonist, enhances behavioural satiety and blocks the hyperphagic effect of orexin-A in rats. Eur J Neurosci. (2001) 13:1444-52. doi: 10.1046/j.0953-816x.2001.01518.x

55. Arch J. Orexins, feeding and the big picture. Br J Nutr. (2000) 84:401-3. doi: 10.1017/S0007114500001707

56. Hara J, Beuckmann CT, Nambu T, Willie JT, Chemelli RM, Sinton CM, et al. Genetic ablation of orexin neurons in mice results in narcolepsy, hypophagia, and obesity. Neuron. (2001) 30:345-54. doi: 10.1016/S0896-6273(01)00293-8

57. Chemelli RM, Willie JT, Sinton CM, Elmquist JK, Scammell T, Lee C, et al. Narcolepsy in orexin knockout mice: molecular genetics of sleep regulation. Cell. (1999) 98:437-51. doi: 10.1016/S0092-8674(00)81973-X

58. Lin L, Faraco J, Li R, Kadotani H, Rogers W, Lin X, et al. The sleep disorder canine narcolepsy is caused by a mutation in the hypocretin (orexin) receptor 2 gene. Cell. (1999) 98:365-76. doi: 10.1016/S0092-8674(00)81965-0

59. Peyron C, Faraco J, Rogers W, Ripley B, Overeem S, Charnay Y, et al. A mutation in a case of early onset narcolepsy and a generalized absence of hypocretin peptides in human narcoleptic brains. Nat Med. (2000) 6:991-7. doi: $10.1038 / 79690$

60. Horvath TL, Diano S, van den Pol AN. Synaptic interaction between hypocretin (orexin) and neuropeptide $\mathrm{Y}$ cells in the rodent and primate hypothalamus: a novel circuit implicated in metabolic and endocrine regulations. J Neurosci. (1999) 19:1072-87. doi: 10.1523/JNEUROSCI.19-03-01072.1999

61. Wang C, Han X, Guo F, Sun X, Luan X, Xu L. Orexin-A signaling in the paraventricular nucleus modulates spontaneous firing of glucose-sensitive neurons and promotes food intake via the NPY pathway in rats. Biochem Biophys Res Commun. (2018) 505:162-7. doi: 10.1016/j.bbrc.2018.09.091

62. Yamanaka A, Kunii K, Nambu T, Tsujino N, Sakai A, Matsuzaki I, et al. Orexin-induced food intake involves neuropeptide Y pathway. Brain Res. (2000) 859:404-9. doi: 10.1016/S0006-8993(00)02043-6

63. Jain MR, Horvath TL, Kalra PS, Kalra SP. Evidence that NPY Y1 receptors are involved in stimulation of feeding by orexins (hypocretins) in sated rats. Regul Pept. (2000) 87:19-24. doi: 10.1016/S0167-0115(99)00102-0

64. Dube MG, Horvath TL, Kalra PS, Kalra SP. Evidence of NPY Y5 receptor involvement in food intake elicited by orexin A in sated rats. Peptides. (2000) 21:1557-60. doi: 10.1016/S0196-9781(00)00311-9

65. Volkoff H, Peter RE. Interactions between orexin A, NPY and galanin in the control of food intake of the goldfish, Carassius auratus. Regul Pept. (2001) 101:59-72. doi: 10.1016/S0167-0115(01)00261-0

66. Yang D, Xu L, Guo F, Sun X, Zhang D, Wang M. Orexin-A and endocannabinoid signaling regulate glucose-responsive arcuate nucleus neurons and feeding behavior in obese rats. Neuropeptides. (2018) 69:26-38. doi: 10.1016/j.npep.2018.04.001

67. Wang C, Kotz CM. Urocortin in the lateral septal area modulates feeding induced by orexin A in the lateral hypothalamus. Am J Physiol Regul Integr Comp Physiol. (2002) 283:R358-67. doi: 10.1152/ajpregu.00558.2001

68. López M, Lage R, Tung YC, Challis BG, Varela L, Virtue S, et al. Orexin expression is regulated by alpha-melanocyte-stimulating hormone. J Neuroendocrinol. (2007) 19:703-7. doi: 10.1111/j.1365-2826.2007. 01577.x

69. Nishino S, Ripley B, Overeem S, Lammers GJ, Mignot E. Hypocretin (orexin) deficiency in human narcolepsy. Lancet. (2000) 355:39-40. doi: 10.1016/S0140-6736(99)05582-8

70. Gerashchenko D, Kohls MD, Greco M, Waleh NS, Salin-Pascual R, Kilduff TS, et al. Hypocretin-2-saporin lesions of the lateral hypothalamus produce narcoleptic-like sleep behavior in the rat. J Neurosci. (2001) 21:7273-83. doi: 10.1523/JNEUROSCI.21-18-07273.2001

71. Date Y, Ueta Y, Yamashita H, Yamaguchi H, Matsukura S, Kangawa K, et al. Orexins, orexigenic hypothalamic peptides, interact with autonomic, neuroendocrine and neuroregulatory systems. Proc Natl Acad Sci USA. (1999) 96:748-53. doi: 10.1073/pnas.96.2.748

72. Peyron C, Tighe DK, van den Pol AN, de Lecea L, Heller HC, Sutcliffe JG, et al. Neurons containing hypocretin (orexin) project to multiple neuronal systems. J Neurosci. (1998) 18:9996-10015. doi: 10.1523/JNEUROSCI.18-23-09996.1998

73. Espana RA, Plahn S, Berridge CW. Circadian-dependent and circadianindependent behavioral actions of hypocretin/orexin. Brain Res. (2002) 943:224-36. doi: 10.1016/S0006-8993(02)02653-7

74. Hagan JJ, Leslie RA, Patel S, Evans ML, Wattam TA, Holmes S, et al. Orexin A activates locus coeruleus cell firing and increases arousal in the rat. Proc Natl Acad Sci USA. (1999) 96:10911-16. doi: 10.1073/pnas.96.19.10911

75. Ida T, Nakahara K, Katayama T, Murakami N, Nakazato M. Effect of lateral cerebroventricular injection of the appetite- stimulating neuropeptide, orexin and neuropeptide $\mathrm{Y}$, on the various behavioral activities of rats. Brain Res. (1999) 821:526-9. doi: 10.1016/S0006-8993(99)01131-2

76. Duxon MS, Stretton J, Starr K, Jones DN, Holland V, Riley G, et al. Evidence that orexin-A-evoked grooming in the rat is mediated by orexin- 1 (OX1) receptors, with downstream 5-HT2C receptor involvement. Psychopharmacology. (2001) 153:203-9. doi: 10.1007/s002130000550

77. Jones DN, Gartlon J, Parker F, Taylor SG, Routledge C, Hemmati P, et al. Effects of centrally administered orexin-B and orexin-A: a role for orexin1 receptors in orexin-B-induced hyperactivity. Psychopharmacology. (2001) 153:210-8. doi: 10.1007/s002130000551

78. Kotz CM, Teske JA, Levine JA, Wang C. Feeding and activity induced by orexin A in the lateral hypothalamus in rats. Regul Pept. (2002) 104:27-32. doi: 10.1016/S0167-0115(01)00346-9

79. Mondal MS, Nakazato M, Date Y, Murakami N, Hanada R, Sakata T, et al. Characterization of orexin-A and orexin-B in the microdissected rat brain nuclei and their contents in two obese rat models. Neurosci Lett. (1999) 273:45-8. doi: 10.1016/S0304-3940(99)00624-2

80. Yamamoto Y, Ueta Y, Serino R, Nomura M, Shibuya I, Yamashita H. Effects of food restriction on the hypothalamic prepro-orexin gene expression in genetically obese mice. Brain Res Bull. (2000) 51:515-21. doi: 10.1016/S0361-9230(99)00271-3

81. Moriguchi T, Sakurai T, Nambu T, Yanagisawa M, Goto K. Neurons containing orexin in the lateral hypothalamic area of the adult rat brain are activated by insulin-induced acute hypoglycemia. Neurosci Lett. (1999) 264:101-4. doi: 10.1016/S0304-3940(99)00177-9

82. Griffond B, Risold PY, Jacquemard C, Colard C, Fellmann D. Insulininduced hypoglycemia increases preprohypocretin (orexin) mRNA in the rat lateral hypothalamic area. Neurosci Lett. (1999) 262:77-80. doi: 10.1016/S0304-3940(98)00976-8

83. Cai XJ, Widdowson PS, Harrold J, Wilson S, Buckingham RE, Arch JR, et al. Hypothalamic orexin expression: modulation by blood glucose and feeding. Diabetes. (1999) 48:2132-7. doi: 10.2337/diabetes.48.11.2132

84. Liu XH, Morris R, Spiller D, White M, Williams G. Orexin a preferentially excites glucose-sensitive neurons in the lateral hypothalamus of the rat in vitro. Diabetes. (2001) 50:2431-7. doi: 10.2337/diabetes.50.11.2431

85. Cai XJ, Liu XH, Evans M, Clapham JC, Wilson S, Arch JR, et al. Orexins and feeding: special occasions or everyday occurrence? Regul Pept. (2002) 104:1-9. doi: 10.1016/S0167-0115(01)00343-3

86. Burdakov D, Gerasimenko O, Verkhratsky A. Physiological changes in glucose differentially modulate the excitability of hypothalamic melaninconcentrating hormone and orexin neurons in situ. J Neurosci. (2005) 25:2429-33. doi: 10.1523/JNEUROSCI.4925-04.2005

87. Yamanaka A, Beuckmann CT, Willie JT, Hara J, Tsujino N, Mieda M, et al. Hypothalamic orexin neurons regulate arousal according to energy balance in mice. Neuron. (2003) 38:701-13. doi: 10.1016/S0896-6273(03)00331-3

88. Tsuneki H, Murata S, Anzawa Y, Soeda Y, Tokai E, Wada T, et al. Age-related insulin resistance in hypothalamus and peripheral tissues of orexin knockout mice. Diabetologia. (2008) 51:657-67. doi: 10.1007/s00125-008-0929-8

89. Tsuneki H, Tokai E, Sugawara C, Wada T, Sakurai T, Sasaoka T. Hypothalamic orexin prevents hepatic insulin resistance induced 
by social defeat stress in mice. Neuropeptides. (2013) 47:213-9. doi: 10.1016/j.npep.2013.02.002

90. Tsuneki H, Tokai E, Nakamura Y, Takahashi K, Fujita M, Asaoka T, et al. Hypothalamic orexin prevents hepatic insulin resistance via daily bidirectional regulation of autonomic nervous system in mice. Diabetes. (2015) 64:459-70. doi: 10.2337/db14-0695

91. Zhu Y, Yamanaka A, Kunii K, Tsujino N, Goto K, Sakurai T. Orexin-mediated feeding behavior involves both leptin-sensitive and -insensitive pathways. Physiol Behav. (2002) 77:251-7. doi: 10.1016/S0031-9384(02)00843-0

92. Becker TM, Favero M, Di MV, Cristino L, Busetto G. Endocannabinoiddependent disinhibition of orexinergic neurons: electrophysiological evidence in leptin-knockout obese mice. Mol Metab. (2017) 6:594-601. doi: 10.1016/j.molmet.2017.04.005

93. Hakansson M, de Lecea L, Sutcliffe JG, Yanagisawa M, Meister B. Leptin receptor- and STAT3-immunoreactivities in hypocretin/orexin neurones of the lateral hypothalamus. J Neuroendocrinol. (1999) 11:653-63. doi: 10.1046/j.1365-2826.1999.00378.x

94. Iqbal J, Pompolo S, Murakami T, Grouzmann E, Sakurai T, Meister B, Clarke IJ. Immunohistochemical characterization of localization of long-form leptin receptor (OB-Rb) in neurochemically defined cells in the ovine hypothalamus. Brain Res. (2001) 920:55-64. doi: 10.1016/S0006-8993(01)02932-8

95. Goforth PB, Leinninger GM, Patterson CM, Satin LS, Myers MG Jr. Leptin acts via lateral hypothalamic area neurotensin neurons to inhibit orexin neurons by multiple GABA-independent mechanisms. J Neurosci. (2014) 34:11405-15. doi: 10.1523/JNEUROSCI.5167-13.2014

96. Sheng Z, Santiago AM, Thomas MP, Routh VH. Metabolic regulation of lateral hypothalamic glucose-inhibited orexin neurons may influence midbrain reward neurocircuitry. Mol Cell Neurosci. (2014) 62:30-41. doi: 10.1016/j.men.2014.08.001

97. Beck B, Richy S. Hypothalamic hypocretin/orexin and neuropeptide Y: divergent interaction with energy depletion and leptin. Biochem Biophys Res Commun. (1999) 258:119-22. doi: 10.1006/bbrc.1999.0605

98. Komaki G, Matsumoto Y, Nishikata H, Kawai K, Nozaki T, Takii M, et al. Orexin-A and leptin change inversely in fasting non-obese subjects. Eur $J$ Endocrinol. (2001) 144:645-51. doi: 10.1530/eje.0.1440645

99. Cai XJ, Lister CA, Buckingham RE, Pickavance L, Wilding J, Arch $J R$, et al. Down-regulation of orexin gene expression by severe obesity in the rats: studies in Zucker fatty and zucker diabetic fatty rats and effects of rosiglitazone. Brain Res Mol Brain Res. (2000) 77:131-7. doi: 10.1016/S0169-328X(00)00041-3

100. Beck B, Richy S, Dimitrov T, Stricker-Krongrad A. Opposite regulation of hypothalamic orexin and neuropeptide $\mathrm{Y}$ receptors and peptide expressions in obese Zucker rats. Biochem Biophys Res Commun. (2001) 286:518-23. doi: 10.1006/bbrc.2001.5420

101. Yamamoto Y, Ueta Y, Date Y, Nakazato M, Hara Y, Serino R, et al. Down regulation of the prepro-orexin gene expression in genetically obese mice. Brain Res Mol Brain Res. (1999) 65:14-22. doi: 10.1016/S0169-328X(98)00320-9

102. Cristino L, Busetto G, Imperatore R, Ferrandino I, Palomba L, Silvestri C, et al. Obesity-driven synaptic remodeling affects endocannabinoid control of orexinergic neurons. Proc Natl Acad Sci USA. (2013) 110:E2229-38. doi: 10.1073/pnas.1219485110

103. Olszewski PK, Li D, Grace MK, Billington CJ, Kotz CM, Levine AS. Neural basis of orexigenic effects of ghrelin acting within lateral hypothalamus. Peptides. (2003) 24:597-602. doi: 10.1016/S0196-9781(03)00105-0

104. Toshinai K, Yamaguchi H, Sun Y, Smith RG, Yamanaka A, Sakurai $T$, et al. Des-acyl ghrelin induces food intake by a mechanism independent of the growth hormone secretagogue receptor. Endocrinology. (2006) 147:2306-14. doi: 10.1210/en.20 05-1357

105. Perello M, Sakata I, Birnbaum S, Chuang JC, Osborne-Lawrence S, Rovinsky SA, et al. Ghrelin increases the rewarding value of high-fat diet in an orexin-dependent manner. Biol Psychiatry. (2010) 67:880-6. doi: 10.1016/j.biopsych.2009.10.030

106. Cone JJ, McCutcheon JE, Roitman MF. Ghrelin acts as an interface between physiological state and phasic dopamine signaling. J Neurosci. (2014) 34:4905-13. doi: 10.1523/JNEUROSCI.4404-13.2014
107. Seoane LM, López M, Tovar S, Casanueva F, Señarís R, Diéguez C. Agoutirelated peptide, neuropeptide $\mathrm{Y}$, and somatostatin-producing neurons are targets for ghrelin actions in the rat hypothalamus. Endocrinology. (2003) 144:544-51. doi: 10.1210/en.2002-220795

108. Cai XJ, Evans ML, Lister CA, Leslie RA, Arch JR, Wilson S, et al. Hypoglycemia activates orexin neurons and selectively increases hypothalamic orexin-B levels: responses inhibited by feeding and possibly mediated by the nucleus of the solitary tract. Diabetes. (2001) 50:105-12. doi: 10.2337/diabetes.50.1.105

109. Álvarez-Crespo M, Martinez-Sanchez N, Ruiz-Pino F, Garcia-Lavandeira M, Alvarez CV, Tena-Sempere M, et al. The orexigenic effect of orexinA revisited: dependence of an intact growth hormone axis. Endocrinology. (2013) 154:3589-98. doi: 10.1210/en.2013-1251

110. Seoane LM, Tovar S, Pérez D, Mallo F, López M, Señarís R, et al. Orexin A suppresses in vivo GH secretion. Eur J Endocrinol. (2004) 150:731-6. doi: 10.1530/eje.0.1500731

111. Karnani MM, Apergis-Schoute J, Adamantidis A, Jensen LT, de LL, Fugger L, et al. Activation of central orexin/hypocretin neurons by dietary amino acids. Neuron. (2011) 72:616-29. doi: 10.1016/j.neuron.2011.08.027

112. Cannon B, Nedergaard J. Brown adipose tissue: function and physiological significance. Physiol Rev. (2004) 84:277-359. doi: 10.1152 /physrev.00015.2003

113. Silva JE. Thermogenic mechanisms and their hormonal regulation. Physiol Rev. (2006) 86:435-64. doi: 10.1152/physrev.00009.2005

114. López M, Alvarez CV, Nogueiras R, Diéguez C. Energy balance regulation by thyroid hormones at central level. Trends Mol Med. (2013) 19:418-27. doi: 10.1016/j.molmed.2013.04.004

115. Bernardis LL, Bellinger LL. The dorsomedial hypothalamic nucleus revisited: 1998 update. Proc Soc Exp Biol Med. (1998) 218:284-306. doi: 10.3181/00379727-218-44296

116. Cerri M, Morrison SF. Activation of lateral hypothalamic neurons stimulates brown adipose tissue thermogenesis. Neuroscience. (2005) 135:627-38. doi: 10.1016/j.neuroscience.2005.06.039

117. Lubkin M, Stricker-Krongrad A. Independent feeding and metabolic actions of orexins in mice. Biochem Biophys Res Commun. (1998) 253:241-5. doi: 10.1006/bbrc. 1998.9750

118. Wang J, Osaka T, Inoue S. Energy expenditure by intracerebroventricular administration of orexin to anesthetized rats. Neurosci Lett. (2001) 315:4952. doi: 10.1016/S0304-3940(01)02322-9

119. Yoshimichi G, Yoshimatsu H, Masaki T, Sakata T. Orexin-A regulates body temperature in coordination with arousal status. Exp Biol Med. (2001) 226:468-76. doi: 10.1177/153537020122600513

120. Martins L, Seoane-Collazo P, Contreras C, Gonzalez-Garcia I, MartinezSanchez N, Gonzalez F, et al. A Functional Link between AMPK and Orexin Mediates the Effect of BMP8B on Energy Balance. Cell Rep. (2016) 16:2231-42. doi: 10.1016/j.celrep.2016.07.045

121. Jaszberenyi M, Bujdoso E, Kiss E, Pataki I, Telegdy G. The role of NPY in the mediation of orexin-induced hypothermia. Regul Pept. (2002) 104:55-9. doi: 10.1016/S0167-0115(01)00339-1

122. Szekely M, Petervari E, Balasko M, Hernadi I, Uzsoki B. Effects of orexins on energy balance and thermoregulation. Regul Pept. (2002) 104:47-53. doi: 10.1016/S0167-0115(01)00348-2

123. Monda M, Viggiano A, Viggiano A, Fuccio F, De L, V. Injection of orexin A into the diagonal band of Broca induces symphatetic and hyperthermic reactions. Brain Res. (2004) 1018:265-71. doi: 10.1016/j.brainres.2004.05.084

124. Zhang W, Sunanaga J, Takahashi Y, Mori T, Sakurai T, Kanmura Y, Kuwaki T. Orexin neurons are indispensable for stress-induced thermogenesis in mice. J Physiol. (2010) 588:4117-29. doi: 10.1113/jphysiol.2010.195099

125. Sellayah D, Bharaj P, Sikder D. Orexin is required for brown adipose tissue development, differentiation, and function. Cell Metab. (2011) 14:478-90. doi: 10.1016/j.cmet.2011.08.010

126. Tupone D, Madden CJ, Cano G, Morrison SF. An orexinergic projection from perifornical hypothalamus to raphe pallidus increases rat brown adipose tissue thermogenesis. J Neurosci. (2011) 31:15944-55. doi: 10.1523/JNEUROSCI.3909-11.2011

127. Madden CJ, Tupone D, Morrison SF. Orexin modulates brown adipose tissue thermogenesis. Biomol Concepts. (2012) 3:381-6. doi: 10.1515/bmc-2011-0066 
128. Morrison SF, Madden CJ, Tupone D. An orexinergic projection from perifornical hypothalamus to raphe pallidus increases rat brown adipose tissue thermogenesis. Adipocyte. (2012) 1:116-20. doi: 10.4161/adip.19736

129. Sellayah D, Sikder D. Orexin receptor-1 mediates brown fat developmental differentiation. Adipocyte. (2012) 1:58-63. doi: 10.4161/adip.18965

130. Sellayah D, Sikder D. Orexin restores aging-related brown adipose tissue dysfunction in male mice. Endocrinology. (2014) 155:485-501. doi: 10.1210/en.2013-1629

131. Russell SH, Small CJ, Sunter D, Morgan I, Dakin CL, Cohen MA, et al. Chronic intraparaventricular nuclear administration of orexin $\mathrm{A}$ in male rats does not alter thyroid axis or uncoupling protein-1 in brown adipose tissue. Regul Pept. (2002) 104:61-8. doi: 10.1016/S0167-0115(01)00349-4

132. Monda M, Viggiano AN, Viggiano A, Viggiano E, Lanza A, De LV. Hyperthermic reactions induced by orexin A: role of the ventromedial hypothalamus. Eur $J$ Neurosci. (2005) 22:1169-75. doi: 10.1111/j.1460-9568.2005.04309.x

133. Yasuda T, Masaki T, Kakuma T, Hara M, Nawata T, Katsuragi I, et al. Dual regulatory effects of orexins on sympathetic nerve activity innervating brown adipose tissue in rats. Endocrinology. (2005) 146:2744-8. doi: 10.1210/en.2004-1226

134. Mohammed M, Ootsuka Y, Yanagisawa M, Blessing W. Reduced brown adipose tissue thermogenesis during environmental interactions in transgenic rats with ataxin-3-mediated ablation of hypothalamic orexin neurons. Am J Physiol Regul Integr Comp Physiol. (2014) 307:R978-89. doi: 10.1152/ajpregu.00260.2014

135. Mohammed M, Yanagisawa M, Blessing W, Ootsuka Y. Attenuated cold defense responses in orexin neuron-ablated rats. Temperature. (2016) 3:46575. doi: 10.1080/23328940.2016.1184366

136. Carling D, Mayer FV, Sanders MJ, Gamblin SJ. AMP-activated protein kinase: nature's energy sensor. Nat Chem Biol. (2011) 7:512-8. doi: $10.1038 /$ nchembio.610

137. Hardie DG, Schaffer BE, Brunet A. AMPK: an energy-sensing pathway with multiple inputs and outputs. Trends Cell Biol. (2016) 26:190-201. doi: 10.1016/j.tcb.2015.10.013

138. Ozcan U, Cao Q, Yilmaz E, Lee AH, Iwakoshi NN, Ozdelen E, et al. Endoplasmic reticulum stress links obesity, insulin action, and type 2 diabetes. Science. (2004) 306:457-61. doi: 10.1126/science.1103160

139. de Morentin PB, López M. "Mens sana in corpore sano": exercise and hypothalamic ER stress. PLoS Biol. (2010) 8:e1000464. doi: 10.1371/journal.pbio.1000464

140. Martínez de Morentin PB, Varela L, Ferno J, Nogueiras R, Diéguez C, López M. Hypothalamic lipotoxicity and the metabolic syndrome. Biochim Biophys Acta. (2010) 1801:350-61. doi: 10.1016/j.bbalip.2009. 09.016

141. López M, Varela L, Vázquez MJ, Rodríguez-Cuenca S, González CR, Velagapudi VR, et al. Hypothalamic AMPK and fatty acid metabolism mediate thyroid regulation of energy balance. Nat Med. (2010) 16:1001-8. doi: $10.1038 / \mathrm{nm} .2207$

142. Martínez de Morentin PB, Whittle AJ, Ferno J, Nogueiras R, Diéguez C, Vidal-Puig A, et al. Nicotine induces negative energy balance through hypothalamic AMP-activated protein kinase. Diabetes. (2012) 61:807-17. doi: $10.2337 / \mathrm{db} 11-1079$

143. Whittle AJ, Carobbio S, Martíns L, Slawik M, Hondares E, Vázquez $\mathrm{MJ}$, et al. Bmp8b increases brown adipose tissue thermogenesis through both central and peripheral actions. Cell. (2012) 149:871-85. doi: 10.1016/j.cell.2012.02.066

144. Seoane-Collazo P, Martinez de Morentin PB, Ferno J, Dieguez C, Nogueiras R, Lopez M. Nicotine improves obesity and hepatic steatosis and ER stress in diet-induced obese male rats. Endocrinology. (2014) 155:1679-89. doi: 10.1210/en.2013-1839

145. Martínez de Morentin PB, Gónzalez-García I, Martins L, Lage R, FernándezMallo D, Martínez-Sánchez N, et al. Estradiol regulates brown adipose tissue thermogenesis via hypothalamic AMPK. Cell Metab. (2014) 20:41-53. doi: 10.1016/j.cmet.2014.03.031

146. Beiroa D, Imbernon $M$, Gallego R, Senra A, Herranz D, Villaroya F, et al. GLP-1 agonism stimulates brown adipose tissue thermogenesis and browning through hypothalamic AMPK. Diabetes. (2014) 63:3346-58. doi: $10.2337 / \mathrm{db} 14-0302$
147. Contreras C, González-García I, Martínez-Sánchez N, Seoane-Collazo P, Jacas J, Morgan DA, et al. Central ceramide-induced hypothalamic lipotoxicity and ER stress regulate energy balance. Cell Rep. (2014) 9:366-77. doi: 10.1016/j.celrep.2014.08.057

148. Martinez de Morentin PB, Lage R, Gonzalez-Garcia I, Ruiz-Pino F, Martins L, Fernandez-Mallo D, et al. Pregnancy induces resistance to the anorectic effect of hypothalamic malonyl-CoA and the thermogenic effect of hypothalamic AMPK inhibition in female rats. Endocrinology. (2015) 156:947-60. doi: 10.1210/en.2014-1611

149. Contreras C, González F, Ferno J, Diéguez C, Rahmouni K, Nogueiras R, et al. The brain and brown fat. Ann Med. (2015) 47:150-68. doi: 10.3109/07853890.2014.919727

150. Imbernon M, Sanchez-Rebordelo E, Romero-Pico A, Kallo I, Chee MJ, Porteiro B, et al. Hypothalamic kappa opioid receptor mediates both diet-induced and melanin concentrating hormone-induced liver damage through inflammation and endoplasmic reticulum stress. Hepatology. (2016) 64:1086-104. doi: 10.1002/hep.28716

151. Contreras C, Gonzalez-Garcia I, Seoane-Collazo P, Martinez-Sanchez N, Linares-Pose L, Rial-Pensado E, et al. Reduction of hypothalamic ER stress activates browning of white fat and ameliorates obesity. Diabetes. (2017) 66:87-99. doi: $10.2337 / \mathrm{db} 15-1547$

152. Martinez-Sanchez N, Moreno-Navarrete JM, Contreras C, Rial-Pensado E, Ferno J, Nogueiras R, et al. Thyroid hormones induce browning of white fat. J Endocrinol. (2017) 232:351-62. doi: 10.1530/JOE-16-0425

153. Martínez-Sánchez N, Seoane-Collazo P, Contreras C, Varela L, Villarroya J, Rial-Pensado E, et al. Hypothalamic AMPK-ER stress-JNK1 axis mediates the central actions of thyroid hormones on energy balance. Cell Metab. (2017) 26:212-29. doi: 10.1016/j.cmet.2017.06.014

154. Seoane-Collazo P, Roa J, Rial-Pensado E, Linares-Pose L, Beiroa D, RuizPino F, et al. SF1-specific AMPKalpha1 deletion protects against diet-induced obesity. Diabetes. (2018) 67:2213-26. doi: 10.2337/db17-1538

155. Linares-Pose L, Rial-Pensado E, Estevez-Salguero A, Milbank E, GonzalezGarcia I, Rodriguez C, et al. Genetic targeting of GRP78 in the VMH improves obesity independently of food intake. Genes. (2018) 9:E357. doi: 10.3390/genes 9070357

156. Cypess AM, Lehman S, Williams G, Tal I, Rodman D, Goldfine AB, et al. Identification and importance of brown adipose tissue in adult humans. $N$ Engl J Med. (2009) 360:1509-17. doi: 10.1056/NEJMoa0810780

157. Marken Lichtenbelt WD, Vanhommerig JW, Smulders NM, Drossaerts JM, Kemerink GJ, Bouvy ND, et al. Cold-activated brown adipose tissue in healthy men. $N$ Engl J Med. (2009) 360:1500-8. doi: 10.1056/NEJMoa0808718

158. Virtanen KA, Lidell ME, Orava J, Heglind M, Westergren R, Niemi T, et al. Functional brown adipose tissue in healthy adults. $N$ Engl J Med. (2009) 360:1518-25. doi: 10.1056/NEJMoa0808949

159. Nedergaard J, Cannon B. The browning of white adipose tissue: some burning issues. Cell Metab. (2014) 20:396-407. doi: 10.1016/j.cmet.2014.07.005

160. Pino MF, Divoux A, Simmonds AV, Smith SR, Sparks LM. Investigating the effects of Orexin-A on thermogenesis in human deep neck brown adipose tissue. Int J Obes. (2017) 41:1646-53. doi: 10.1038/ijo.2017.155

161. Morales DN, Romu T, Landtblom AM, Szakacs A, Hallbook T, Darin N, et al. Unexpected fat distribution in adolescents with narcolepsy. Front Endocrinol. (2018) 9:728. doi: 10.3389/fendo.2018.00728

162. Enevoldsen LH, Tindborg M, Hovmand NL, Christoffersen C, Ellingsgaard $\mathrm{H}$, Suetta $\mathrm{C}$, et al. Functional brown adipose tissue and sympathetic activity after cold exposure in humans with type 1 narcolepsy. Sleep. (2018) 41:zsy092. doi: 10.1093/sleep/zsy092

163. Vella KR, Ramadoss P, Lam FS, Harris JC, Ye FD, Same PD, et al. NPY and MC4R signaling regulate thyroid hormone levels during fasting through both central and peripheral pathways. Cell Metab. (2011) 14:780-90. doi: 10.1016/j.cmet.2011.10.009

164. Alvarez-Crespo M, Csikasz RI, Martinez-Sanchez N, Dieguez C, Cannon B, Nedergaard J, et al. Essential role of UCP1 modulating the central effects of thyroid hormones on energy balance. Mol Metab. (2016) 5:271-82. doi: 10.1016/j.molmet.2016.01.008

165. López M, Seoane LM, Tovar S, García MC, Nogueiras R, Diéguez C, et al. A possible role of neuropeptide $\mathrm{Y}$, agouti-related protein and 
leptin receptor isoforms in hypothalamic programming by perinatal feeding in the rat. Diabetologia. (2005) 48:140-8. doi: 10.1007/s00125-00 4-1596-z

166. López M, Tovar S, Vázquez MJ, Nogueiras R, Seoane LM, García M, et al. Perinatal overfeeding in rats results in increased levels of plasma leptin but unchanged cerebrospinal leptin in adulthood. Int J Obes. (2007) 31:371-7. doi: $10.1038 /$ sj.ijo.0803425

167. Thompson MD, Xhaard H, Sakurai T, Rainero I, Kukkonen JP. OX1 and OX2 orexin/hypocretin receptor pharmacogenetics. Front Neurosci. (2014) 8:57. doi: $10.3389 /$ fnins.2014.00057
Conflict of Interest: The authors declare that the research was conducted in the absence of any commercial or financial relationships that could be construed as a potential conflict of interest.

Copyright (๑) 2019 Milbank and López. This is an open-access article distributed under the terms of the Creative Commons Attribution License (CC BY). The use, distribution or reproduction in other forums is permitted, provided the original author(s) and the copyright owner(s) are credited and that the original publication in this journal is cited, in accordance with accepted academic practice. No use, distribution or reproduction is permitted which does not comply with these terms. 